\title{
ÚTEIS A SI E À NAÇÃO: A CRIANÇA NO PROCESSO DE TRANSIÇÃO DO SISTEMA DE TRABALHO - BRASIL, SEGUNDA METADE DO SÉCULO XIX
}

\author{
Heloísa Maria Teixeira* \\ lattes.cnpq.br/5764326196328206
}

\begin{abstract}
Resumo: A segunda metade do século XIX caracterizou-se, fundamentalmente, pelo declínio da escravidão e, por consequência, pelas discussões acerca das alternativas de trabalho que substituiriam o sistema baseado na mão de obra mancípia. Sobre as formas de substituição da mão de obra cativa, as opiniões dos escravistas eram divergentes: imigrantes ou trabalhador nacional? Para aqueles que apostavam no trabalhador nacional (livres pobres, libertos e ingênuos), seria importante a efetivação de medidas para melhor aproveitamento dessa mão de obra. Entre as medidas estava o desenvolvimento de instituições de ensino que permitissem sua qualificação. Diante desse processo de transformação, as crianças pobres, muitas vezes, descendentes de escravos, eram especialmente interessantes, pois poderiam ser educadas desde cedo para atender às novas expectativas de trabalho. Nosso artigo analisa a criança pobre nos discursos oficiais (Relatórios e Mensagens dos Presidentes de Província; Anais do Congresso Mineiro) e na legislação referentes ao período de 1850-1900. Veremos que, entre as propostas do Estado, estava a de formar/educar a criança desvalida, muitas vezes descendente da escravidão, para o trabalho na lavoura através de instituições educacionais voltadas para a aprendizagem na agricultura e ofícios. Ao final do processo de formação da criança, esperava-se encontrar um trabalhador adequado ao sistema de trabalho que substituiria o trabalho escravo. Nesse sentido, as crianças passam a ser vistas como verdadeiras responsáveis pelo devir; futuros cidadãos sobre os quais recairiam as tarefas de elevação da pátria ao progresso e à modernização.
\end{abstract}

Palavras-chave: Infância pobre; Educação para o trabalho; Transição para o trabalho livre.

\section{USEFUL TO THEMSELVES AND TO THE NATION: THE CHILD IN THE TRANSITION PROCESS OF THE WORK SYSTEM - MINAS GERAIS, SECOND HALF OF THE NINETEENTH CENTURY}

\footnotetext{
* Doutora em História Econômica pela Universidade de São Paulo (Brasil). Contato: heloisate@hotmail.com.
} 


\begin{abstract}
The second half of the nineteenth century was fundamentally characterized by the decline of slavery and, consequently, by debates about alternative work that would replace the system based on captive labor. Upos those alternatives, the slavers judgment were divergent: foreign or national worker? For those who chose the national worker (free poors, freedmen and ingênuos), it would be important to implement steps to make better use of this workforce. The development of educational institutes in order to their qualification was one of that steps. On this process, poor children, often descendants of slaves, were especially interesting because they could be educated to fulfill completely new expectations. We propose to analyze the poor child in the official speeches (Reports and Messages of the provincial Presidents, Congress of Minas Gerais Annals) and in the legislation of 1850-1900. The State proposals includes to educate the disadvantaged child, often descendants of slaves, to labor in farming through educational institutes for learning in agriculture and crafts. At the end of the child training, it was expected a suitable worker to the system that would replace slave labor. In this sense, children turn into responsible for to become; future citizens on whom the tasks of homeland raising to progress and modernization would fall.
\end{abstract}

Keywords: Poor childhood; Education for work; Transition to free labor.

* * *

A segunda metade do século XIX caracterizou-se, fundamentalmente, pelo declínio da escravidão e, por consequência, pelas discussões acerca das alternativas de trabalho que substituiriam o sistema baseado na mão de obra mancípia. A partir da proibição da entrada de africanos no Brasil na condição de escravos, em 1850, a reprodução seria o meio de perpetuação do sistema escravista de trabalho. Essa forma de reposição foi eliminada quando instituída a lei que, em setembro de 1871, libertou o ventre das escravas. Desde então, acirraram-se as discussões sobre os meios de contornar a crise provocada pela legislação de 1871 que, além do ventre livre, instituiu um fundo financeiro que tinha como propósito a emancipação de escravos e permitia ao cativo a acumulação de pecúlio para ser usado na compra da própria alforria.

O fim da escravidão estava anunciado e, sobre as formas de substituição da mão de obra cativa, as opiniões dos escravistas eram divergentes: imigrantes ou cooptação do trabalhador nacional? Observando os senhores do Sudeste, como ilustração, percebemos que, 
enquanto parte dos cafeicultores do Oeste Paulista defendia um projeto de transição da mão de obra utilizando trabalhadores imigrantes, os lavradores de Minas, Rio de Janeiro, Espírito Santo e os paulistas representantes do Vale do Paraíba defendiam o emprego da mão de obra nacional (GEBARA, 1986; KOWARICK, 1987; LANNA, 1989; COSTA, 1998; COSTA, 1999).

Nas regiões que apostavam no trabalhador nacional (livres pobres, libertos e ingênuos), seria importante a efetivação de medidas para melhor aproveitamento dessas pessoas. Para tanto, as propostas que visavam adequar a mão de obra nacional à nova conjuntura pensavam no desenvolvimento de instituições de ensino que permitissem sua qualificação. Durante o congresso de 1878, ocorrido no Rio de Janeiro, a questão da instrução dos trabalhadores nacionais foi discutida e vista como a necessidade mais urgente da agricultura, pois, educados, transformar-se-iam em elementos úteis e definitivos para a lavoura. Diante desse processo de transformação, as crianças eram especialmente interessantes, pois poderiam ser educadas desde cedo para atender às novas expectativas de trabalho.

Este texto pretende analisar a criança pobre nos discursos referentes ao processo de transformação do trabalho no Brasil. Veremos que, entre as propostas do Estado, estava a de formar/educar a criança desvalida, muitas vezes descendente da escravidão, para o trabalho na lavoura. Utilizaremos como fontes os discursos oficiais e a historiografia que discute as alternativas para a substituição do sistema escravista.

\section{Educação: caminho para a civilização e o progresso}

Os Anais da Assembleia Constituinte, resultados das discussões do legislativo entre os meses de maio e novembro de 1823, reúnem documentos que relatam os projetos políticos para definir o futuro da recém-instituída nação brasileira. Entre os projetos, estava a difusão da 
instrução e do ensino aos habitantes do Império, fundamentalmente entre as crianças.

Era a primeira vez que o termo criança aparecia no contexto da construção do Estado. Entretanto, havia somente algumas poucas referências, as quais, segundo Martha Abreu e Alessandra Martinez, demonstravam que a problemática da criança, inserida nas discussões sobre a instrução pública, apenas começava a insinuar-se entre os projetos de construção da jovem nação brasileira (ABREU; MARTINEZ, 1997).

Na década de 1830, pensando na instrução de crianças pobres a fim de formar um contingente profissional para atuar na Marinha e na Guerra, o Império determinou o envio de órfãos desvalidos para esses arsenais ${ }^{1}$. $\mathrm{Na}$ década seguinte, foram instituídas as Companhias de Aprendizes Artífices e as Companhias de Aprendizes Marinheiros. Iniciava-se, assim, a formação compulsória de trabalhadores para diversos ofícios através do encaminhamento de crianças e adolescentes às oficinas dos arsenais militares de Guerra e da Marinha. O objetivo central era evitar que crianças desvalidas se tornassem futuros vadios, inúteis e perigosos à sociedade ${ }^{2}$.

A política de atenção à infância pobre intensificou-se nos anos 1850 com a criação de Asilos de Educandos em quase todas as capitais provinciais. Segundo Maria Luiza Marcílio,

a ideologia que fundamentou essas novas instituições incluía a instrução elementar, a formação cívica e a capacitação profissional das crianças desvalidas, que assim não seriam "entregues a si mesmas, senão depois de terem cumprido os deveres do homem para com a Nação, defendendo-a, e

\footnotetext{
1 A promulgação das leis que determinavam o envio de órfãos desvalidos para os arsenais da Guerra e da Marinha data, respectivamente, de 1832 e 1835 (PINHEIRO, 2003, p. 50).

2 "Até o início da década de 1840, as Companhias de Aprendizes dos Arsenais não estavam regulamentadas, dando origem a muitos abusos, maus-tratos e exploração de menores. Em 1842 aprovaram-se os estatutos da Companhia de Menores da Guerra e, em 1850, os da Marinha. No Arsenal da Guerra, a idade mínima de admissão foi fixada em 8 anos e só seriam admitidos os 'expostos, os órfãos indigentes; os menores que viverem abandonados, sem superior que vele pela sua educação; os filhos de pais que, por sua pobreza, não tiverem meios de alimentar e educar'.” (MARCÍLIO, 1998, p. 186).
} 
habilitadas para só dependerem de seus braços e da sua habilidade (MARCÍLIO, 1998, p. 193)3.

Para a autora, a motivação desse projeto fora a abolição do tráfico africano de escravos - que provocou nas elites o temor de passarem por carências no suprimento da mão de obra doméstica e agrícola -, mas vinha também no rastro das duas grandes epidemias que assolaram o país e que deixaram uma legião de crianças órfãs e desamparadas: a da febre amarela (1849) e a do cólera (1855). As angústias vivenciadas pelos presidentes das províncias acerca do processo de transição foram representadas pela autora com a fala do presidente da província do Maranhão que, ao fundar um asilo para meninas desamparadas em São Luís, afirmou que o

objetivo principal da instituição (...) estava na necessidade social de se procurarem braços livres que substituirão os escravos nos diferentes encargos do serviço doméstico. (...). No Asilo do Maranhão, as internas aprendiam, além do ensino fundamental, prendas do lar e noções gerais de música, história, geografia e gramática nacional (Relatório do Presidente da Província do Maranhão de 1850, p. 24, apud MARCÍLIO, 1998, p. 202-205).

As meninas desvalidas de Mariana, Minas Gerais, no ano de 1848, passaram a contar com o apoio das freiras vicentinas, recém-chegadas da França e que, a partir de então, dariam início à obra de educação das meninas pobres e expostas. Este acontecimento foi relatado pelo presidente da província mineira, no ano de 1850, que exaltava o prelado

\footnotetext{
3 Maria Luiza Marcílio lembra que essas medidas introduzidas no Brasil na segunda metade do século XIX foram fundamentadas em teorias surgidas na Europa do século XVIII. Segundo a autora, "o fisiocratismo propugnava que elas [as crianças abandonadas] deviam ser preparadas para se tornarem bons agricultores. Na França, essas teorias chegaram a sensibilizar as autoridades. Em 1769, o Conselho de Estado oferecia uma pensão - de 12 a 40 libras - a todo chefe de família rural que criasse uma criança abandonada. As teorias ilustradas julgavam ainda que os expostos deveriam tornar-se bons soldados (substitutos ideais para os filhos de família sorteados para o serviço da milícia). A pátria os nutriria, pois os expostos pertencem a ela, são os filhos do estado; em compensação, esses filhos da pátria deveriam prestar serviços a ela, serem 'utéis a si e à nação'. O utilitarismo do século XVIII vê com horror a alta mortalidade dos expostos: são cidadãos úteis que a pátria não deveria perder. Eles poderiam servir nos exércitos ou trabalhar em serviços pesados; ou poderiam ser embarcados para as colônias que a Europa conquistara na América, na África, na Ásia” (MARCÍlLIO, 1998, p. 72).
} 
por ter possibilitado a vinda das "filhas da caridade - que se estão estabelecendo na cidade de Mariana" (Relatório do Presidente da Província de Minas Gerais, o Illmo e Exmo sr. Dr. Alexandre Joaquim de Siqueira em 1850, p.17-18). No relatório da Assembleia Provincial de 1851, disse o presidente José Ricardo de Sá Rego:

o estabelecimento das irmãs de caridade progride admiravelmente. As 12 senhoras que o regem são as mais hábeis que poderíamos desejar. Compõem-se o colégio de cinquenta e tantas meninas, que além de primeiras letras, aritmética, geografia e francês, aprendem a bordar, fazer flores etc. As irmãs as tratam com carinho e doçura de mães. Este colégio não tem renda alguma, e assim mesmo com regulada economia das irmãs, acode e entretem algumas meninas desvalidas (Relatório que a Assembléia Provincial de Minas Gerais apresentou na sessão ordinária de 1851, p.9)4.

Também para Mariana, no relatório de 1850, o presidente da província menciona a inauguração de um colégio de órfãos para o sexo masculino subvencionado pelo bispado, sugerindo, assim, a existência de dois estabelecimentos na cidade destinados separadamente a meninas e meninos:

deve também a província o zelo do Exmo. Bispo Diocesano a inauguração de um colégio de meninos órfãos na cidade de

4 Em 1861, falava-se em 113 meninas no colégio das irmãs, "das quais 12 são conservadas sem pagamento, e 40 são órfãs pobres miseráveis recolhidas pela caridade das irmãs, sustentadas, vestidas, tratadas, e educadas por elas" (Relatório que a Assembleia Provincial de Minas Gerais apresentou na abertura da sessão ordinária de 1861, p.12). A educação das meninas órfãs no colégio das irmãs foi consequência de uma lei provincial datada de 16 de outubro de 1861. Segundo essa lei, o Estado auxiliaria o colégio anualmente com a quantia de Rs. 6:00o\$00o "para o fim de serem ali recebidas 40 órfãs pobres da província designadas pelo governo" (Relatório que ao ilustríssimo e excelentíssimo sr.dr. Fidelis de Andrade Botelho, quarto vice-presidente da província de Minas Gerais apresentou no ato de passar a administração, em 2 de abril de 1864, p.16). O relatório do presidente da província de Minas Gerais do ano de 1864, no quadro de número 3A, revela que as meninas órfãs pobres educadas no colégio das irmãs no ano anterior eram 52, divididas em duas classes e que aprendiam "doutrina, ler, escrever, contar, costura e flores" (Relatório que ao ilustríssimo e excelentíssimo sr. dr. Fidelis de Andrade Botelho, quarto vice-presidente da província de Minas Geras apresentou no ato de passar a administração, em 2 de abril de 1864, p.16). 
Mariana, sem outros fundos além dos que lhe sugerira sua engenhosa caridade. Dirigiu-se aos párocos da província, como sabereis, enviando lhes pequenos folhetos pios e estampas de santos para a estação da missa conventual os distribuírem pelos fiéis mediante uma esmola não menor de 40 réis, e é com esse tão precário subsídio que abriu o colégio, onde já tem bom número de meninos. Não posso deixar de recomendar a vossa esclarecida proteção para tão pio estabelecimento5.

A educação era o meio mais defendido na busca do ideal de civilização e progresso da nação brasileira, mas esbarrava no problema da desestruturação da instrução pública. Em 1854, aconteceu uma das primeiras medidas relevantes no campo da instrução pública no Brasil. Foi nesse ano que o Ministro e Secretário dos Negócios do Império, Luiz Couto Ferraz, elaborou um regulamento para a reforma dos ensinos primário e secundário destinados ao município da Corte. O projeto previa a construção de escolas de primeiro grau e a criação de escolas normais com intuito de garantir a preparação do corpo docente. De acordo com o projeto, deveriam ser matriculados nas escolas públicas ou particulares subvencionadas pelo Estado os menores de 12 anos que se encontrassem vagando pelas ruas, em estado de pobreza e indigência (MARTINEZ, 1997, p. 157). Foi proposta, também, a criação de um asilo que ministrasse educação primária e profissional aos meninos desvalidos. Analisando a política do governo da Corte de instruir crianças pobres, Alessandra Martinez afirma que

a instrução primária foi entendida como a instrução popular, por
excelência, destinada a toda a população live. Incluindo as
crianças provenientes de famílias pobres, a escola primária
pretendia constituir um espaço de integração e inclusão social,
preparando-as para a aquisição futura de uma instrução
profissional. Por outro lado, ao limitar ao nível primário a “dívida
sagrada e restrita” do Estado, a escola também buscava excluir,
criando e recriando hierarquias, diferenciando as crianças pobres

5 Relatório do Presidente da Província de Minas Gerais, o ilmo. e exmo. sr. dr. Alexandre Joaquim de Siqueira em 1850, p.18. Sobre o colégio dos órfãos, diz o relatório de 1851 "que tem como objetivo tirar os meninos pobres da mendicidade, educá-los em primeiras letras, e ensinar-lhes ofícios mecânicos” (Relatório que a Assembléia Provincial de Minas Gerais apresentou na sessão ordinária de 1851, p. 9). 
daquelas pertencentes à "boa sociedade"( MARTINEZ, 1997, p.158).

De acordo com o Regulamento de 1854, “os meninos pobres só poderiam dar continuidade aos estudos no caso de demonstrarem acentuada distinção e 'capacidade' para tal, habilidades quase nunca reconhecidas” (MARTINEZ, 1997, p. 157). Dessa forma, depois de frequentar as aulas primárias, a maioria dos meninos residentes na Corte seria enviada aos arsenais de Marinha e de Guerra ${ }^{6}$ ou às oficinas particulares para a aprendizagem de ofícios que lhes garantissem sustento e trabalho.

A política de expansão da instrução primária também estava sendo pensada na província mineira durante a segunda metade do século XIX. De acordo com o relatório de província do ano de 1851, o número de alunos matriculados nas escolas públicas em 1846 era de 4.614. Quatro anos depois esse número subiu para 8.770 meninos e meninas matriculados7. Em 1861 o número de alunos era 12.815, sendo 11.926 matriculados na instrução primária (10.383 do sexo masculino e 1.543 do sexo feminino) e 889 na instrução secundária ${ }^{8}$. Esse aumento do número de alunos era consequência da política educacional da província mineira que visava expandir a instrução primária. $\mathrm{O}$ mesmo não acontecia com a instrução secundária, conforme nos revelam os números acima mencionado. Vejamos o questionamento do presidente da província, sr. dr. Alexandre Joaquim de Siqueira, quando da apresentação do relatório do ano de 1850 sobre a expansão da instrução secundária em Minas Gerais:

\footnotetext{
6 Entre 1840 e 1864, proliferaram pelas províncias brasileiras as Companhias de Aprendizes Artífices e as Companhias de Aprendizes Marinheiros. Sobre a utilização da mão de obra de menores pobres pelas Forças Armadas, consultar VENÂNCIO, 2002; SOUZA, 1998. Venâncio e Souza salientam que inúmeros foram os casos de garotos pobres, órfãos ou não, que tiveram sua força de trabalho amplamente utilizada em serviços militares no decorrer do século XIX, fosse através do recrutamento forçado, do encaminhamento dos juízes de órfãos e das chefias de polícia ou até mesmo pela inscrição dos responsáveis pelos menores.

7 Relatório que a Assembléia Provincial de Minas Gerais apresentou na sessão ordinária de 1851, p.8.

8 Relatório que a Assembléia Provincial de Minas Gerais apresentou na abertura da sessão ordinária de 1861, p.11.
} 
o que lucra a província com semelhante educação? Aumentar a chusma dos famélicos pretendentes aos empregos públicos, deslocando assim numerosos braços, que podiam ser utilizados nos diversos ramos da indústria 9 .

No relatório que a assembleia legislativa mineira apresentou no ano de 1865, a instrução primária era descrita como "agente fecundo da civilização e do progresso”. Vejamos o que disseram nossos legisladores:

Não é simplesmente por sua importância política que a instrução do povo deve ser considerada como necessidade social. (...). Se a instrução do povo é por sua importância política, civil e industrial, uma necessidade social, corre ao estado a obrigação de manter um ensino público que a ministre. (...). Bem avisado andou pois o legislador constituinte, quando no artigo 179 da nossa lei fundamental garantiu ao cidadão brasileiro o direito à instrução, e fez do ensino uma obrigação do poder público. Mas é necessário distinguir na instrução popular o útil e o indispensável. O fim do ensino primário não é, como o do ensino secundário e superior, preparar o homem para esta ou para aquela profissão; ele limita-se a formar o homem, isto é, a darlhe aquela instrução e educação indispensáveis ao indivíduo e ao cidadão. Leitura e escrita, meios de aquisição de todos os conhecimentos, cálculo no que ele tem de mais imediatamente aplicável aos usos da vida, noções sobre os direitos e deveres sociais e religiosos, eis ali o indispensável, o mínimo da instrução, de que não pode prescindir aquele que aspira os foros de cidadão de um país civilizado ${ }^{10}$.

Entretanto, conforme nos informa o mesmo relatório, o acesso às crianças pobres a educação pública era limitado, pois na

classe pobre, o desejo de aproveitar os pequenos serviços que pode prestar uma criança, e sobretudo o pouco apreço que dão à

9 Relatório do Presidente da Província de Minas Gerais, o ilmo. e exmo. sr. dr. Alexandre Joaquim de Siqueira em 1850, p.16. O relatório de 1881 traz os seguintes números para os alunos matriculados na instrução primária da província mineira: em 1870, eles eram 14.667; em 1871, 15.620 alunos; 1872, 18.450; em 1873, 21.182; em 1875, 23.319; em 1879, 32.297 alunos (Relatório que a assembléia legislativa provincial de Minas Gerais por ocasião de ser instalada a mesma assembléia para a $2^{\mathrm{a}}$ sessão ordinária de $23^{\text {a }}$ legislatura em 7 de agosto de 1881, p. 55).

${ }_{10}$ Relatório que a Assembléia Provincial de Minas Gerais apresentou no ato da abertura da sessão ordinária de 1865, p. A.18-19. 
instrução aqueles que não a possuem, induzem os pais das famílias pobres a afastarem seus filhos das escolas, quando são precisamente estes os que mais precisam de instrução, para não fraquejarem na luta que têm de sustentar contra as privações da vida, e as tentações da miséria. Antes dos 7 anos quase que a criança não pode viver fora da família: antes de 12 nenhum serviço pode prestar a seus pais. Seja pois o período intermediário destinado a sua educação e instrução ${ }^{11}$.

Objetivando reverter esse cenário, a Província mineira, em 1835, torna obrigatória à frequência das crianças nas escolas públicas de instrução primária. Para as famílias que descumprissem a legislação, uma multa seria imposta nos seguintes valores: de "Rs. 5 \$ooo no primeiro mês, Rs. 10 \$000 no segundo, Rs. $15 \$$ Ooo no terceiro, que conserve sempre esta mesma proporção, mas em caso algum possa exceder a Rs. 50\$000"12. Entretanto, diante da pobreza instituída no meio familiar das muitas crianças que se ausentavam das escolas públicas mineiras, a aplicação das multas não foi efetiva.

\section{Os filhos livres das escravas: agentes passivos do processo de transição}

Na década de 1850, efetivamente, fortaleceu-se a ideia de superação do escravismo no Brasil. A primeira medida com esse propósito foi o corte do abastecimento externo de escravos. A partir de então, avolumaram-se as discussões em torno de como deveria ocorrer o processo de transição do sistema de trabalho escravo para o livre. Propostas baseadas na transição imediata foram pensadas, mas prevaleceram aquelas que buscavam uma transição gradual, permitindo, assim, reflexões em torno dos mecanismos de substituição dos trabalhadores mancípios. Entre as propostas, vingou a que via na libertação do ventre das escravas a forma de superação da escravidão. Tal proposta seria a forma de encaminhar a extinção da

${ }^{11}$ Relatório que a Assembléia provincial de Minas Gerais apresentou no ato da abertura da sessão ordinária de 1865, p. A. 21.

12 Ibidem. 
escravidão em longo prazo, permitindo aos proprietários adaptarem-se à nova conjuntura.

Entre os maiores defensores dessa vertente, estava Perdigão Malheiro, que em 1867 publicou o terceiro volume de sua obra $A$ escravidão no Brasil. Malheiro afirmava que a abolição imediata era inadmissível em razão do grande número de escravos - 1,5 milhão nos cálculos do autor. Segundo Malheiro, tornando-se realidade a abolição imediata, não só a propriedade escrava seria atacada, como também resultaria em problema para os próprios escravos expostos à liberdade sem nenhuma preparação prévia. Na perspectiva do autor, a abolição da escravidão deveria partir da libertação dos ventres das escravas. Dessa forma, o sistema escravista seria acometido de modo gradual a partir de sua raiz, o ventre da escrava, que, desde o bloqueio do tráfico internacional, era a fonte capaz de perpetuar o escravismo.

À medida que a proposta da abolição gradual a partir do ventre livre das escravas fortalecia-se, uma nova discussão surgia: o que fazer dos filhos das escravas nascidos livres da condição de cativos? O projeto defendido por Malheiro orientava que, embora essas crianças nascessem livres, elas ficariam sob a tutela dos senhores de suas mães, que seriam os responsáveis pela educação das mesmas e, em troca, poderiam utilizá-las como trabalhadores até que atingissem a maioridade. Como argumento de defesa, Malheiro chama atenção para as vantagens da disposição aos senhores do direito de utilizar os serviços dessas crianças. Segundo seus cálculos,

uma criança de 7 anos já começa a prestar alguns serviços apropriados às suas forças; de 12 ainda melhor; de 16 a 21 anos muito mais: ora, calculando (termo médio) em Rs. $150 \$ 000$ por ano o valor do serviço prestado só nos últimos anos, temos que nos cinco anos ele seria de Rs. 750\$0oo; preço médio de um bom escravo (MALHEIRO, 1976, p. 158).

Sobre a educação ideal dessas crianças, Malheiro afirmou que deveria ser 
locais. O essencial é que além da educação moral e religiosa, tomem uma profissão, ainda que sejam lavradores ou trabalhador agrícola; ele continuará a servir aí se lhe convier, ou irá servir a outrem, ou se estabelecerá sobre si; em todo o caso, aprenda um ofício mecânico, uma profissão, de que possa tirar recursos para se manter e a família, se tiver. Alguns poderão mesmo ser aproveitados nas letras ou em outras profissões, as escolas lhes são francas, como livres que serão por nascimento (MALHEIRO, 1976, p. 162).

A proposta de emancipação do ventre da mulher escrava provocou a emergência de uma série de discursos e projetos voltados para a "proteção", "educação" e "amparo" dos ingênuos a fim de garantir-lhes a efetiva liberdade. Por outro lado, surgiam também ideias que se opunham a essas questões por acreditarem que educar os ingênuos representava contrariar os interesses imediatos dos proprietários de escravos, não dispostos a aceitar uma mudança efetiva na condição desses indivíduos tidos como os futuros trabalhadores do país.

Marcus Vinícius Fonseca (2002, p. 50), analisando o aspecto educacional do processo de transição do sistema de trabalho no Brasil através dos documentos oficiais ${ }^{13}$ correspondentes ao período 1867-1889, verificou que para os senhores de escravos

a liberdade do ventre não poderia vir associada a uma mudança efetiva de status das crianças que nascessem livres. Como consequência, defenderam aquilo que poderíamos chamar de uma liberdade híbrida: uma liberdade que deveria existir entre a garantia no texto da lei e a realidade de uma existência que iria transcorrer em meio ao cotidiano da escravidão, entre uma infância e juventude escrava e uma condição de liberdade formal na fase adulta.

O texto final da lei que efetivava o ventre livre das escravas aspirou atender aos anseios dos escravistas, estabelecendo como legítima a relação entre ingênuos e trabalho.

Diz a Lei 2.040, de 28 de setembro de 1871:

$13 \mathrm{O}$ autor baseou-se em Falas do Trono, relatórios e anexos aos relatórios dos ministros e secretários de Estado dos Negócios da Agricultura, Comércio e Obras Públicas (FONSECA, 2002). 
Os filhos da mulher escrava, que nascerem no império desde a data desta lei, serão considerados de condição livre. Os ditos filhos menores ficarão em poder e sob a autoridade dos senhores de suas mães, os quais terão a obrigação de criá-los e tratá-los até a idade de oito anos completos. Chegando o filho da escrava a esta idade, o senhor da mãe terá a opção ou de receber do Estado a indenização de Rs. $600 \$ 000$, ou de utilizar-se dos serviços do menor até a idade de 21 anos completos. No primeiro caso o governo receberá o menor, e lhe dará destino, em conformidade com a lei. (...). O governo poderá entregar a associações por ele autorizadas, os filhos das escravas, nascidos desde a data desta lei, que sejam cedidos ou abandonados pelos senhores delas, ou tirados do poder destes em virtude do artigo $1^{\circ}$ parágrafo $6^{\circ}$ [que se refere a maus-tratos aos ingênuos]. As ditas associações terão direito aos serviços gratuitos dos menores até a idade de 21 anos completos, e poderão alugar esses serviços, mas serão obrigadas: 1) a criar e tratar os mesmos menores; 2) a constituir para cada um deles um pecúlio, consistente na quota que para este fim for reservada nos respectivos estatutos; 3) a procurar-lhes, findo o tempo de serviço, apropriada colocação. (...). A disposição deste artigo é aplicável às casas dos expostos, e às pessoas a quem os juízes de Órfãos encarregarem a educação dos ditos menores, na falta de associações ou estabelecimentos criados para tal fim (Lei $\mathrm{n}^{0}$ 2.040, de 28 de setembro de 1871, apud, ALANIZ, 1997).

O texto da Lei 2.040 pretendeu, além de proclamar o ventre livre das escravas, tornar explícito que, apesar de nascerem livres, os filhos das escravas não se livrariam da associação ao trabalho atribuída a seus pais. As palavras criar e educar, empregadas para qualificar a relação entre escravistas e ingênuos ou entre Estado e ingênuos, somente serão compreendidas quando associadas à formação de trabalhadores. Em vários momentos, no corpo da lei, a obrigação dos ingênuos com a prestação de serviços a seus criadores/educadores é mencionada, indicando, dessa forma, a intenção da lei.

Autores dedicados à interpretação da legislação de 1871 estabelecem distinções entre as denominações criar e educar. Na análise de Fonseca,

em todas as dimensões em que se poderia atribuir uma obrigação aos senhores quanto às crianças que seriam retidas nas fazendas, não sendo trocadas pela indenização, o termo educação foi substituído por criação. Esta distinção entre criação e educação demonstra que nesse aspecto, a lei defende os interesses dos proprietários, isentando-os de qualquer responsabilidade quanto 
à educação, ou melhor, instrução, das crianças nascidas livres de mulher escrava (FONSECA, 2002, p.53).

Para o autor, a diferença entre criação e educação consistia em essa última assegurar a instrução elementar para os filhos livres das escravas, sendo garantida apenas para as crianças que seriam entregues pelos senhores ao governo em troca da indenização de Rs. 600\$00o. Entretanto, somente o texto da Lei 2.040 não é suficiente para esclarecer possíveis diferenças existentes entre criação e educação dos ingênuos. A palavra educação aparece apenas uma vez na legislação e desassociada da palavra instrução escolar.

Criação e educação seriam palavras sinônimas que definiriam as obrigações do Estado ou dos senhores em relação às crianças ingênuas. Tanto as crianças entregues ao Estado quanto as que permaneceram nas propriedades escravistas foram criadas/educadas para o mesmo propósito: o trabalho. Sobre as instituições criadas para receber os ingênuos, Maria Luiza Marcílio observa que tinham propósitos claros e bastante semelhantes aos objetivos dos escravistas com relação aos filhos livres das escravas e sua formação para o trabalho. A autora exemplifica essa questão utilizando-se do discurso inaugural proferido pelo presidente da província baiana acerca da Colônia Orfanológica Isabel, localizada em Salvador, que buscava

ajudar a transição do trabalho escravo para o livre, dando à lavoura operários nacionais bem-educados, instruídos e moralizados, acostumados ao trabalho metódico e perseverante, e capazes de afrontar sem receios os rigores do nosso clima, de aumentar a produção de riqueza com o trabalho e esforços de numerosos indivíduos (...) de aumentar a população útil e sã, com famílias legítimas que serão formadas por esses indivíduos anos depois (MARCÍLIO, 1998, p. 213).

As instituições que recebessem as crianças poderiam utilizá-las na prestação de serviços, mas, em contrapartida, era exigido por parte do Estado que certo grau de escolarização fosse dado às crianças nascidas livres de mãe escrava, sendo essa escolarização concebida como algo 
indispensável para o exercício da vida livre que deveriam ter depois dos 21 anos (FONSECA, 2002, p. 56-57).

A preocupação com o futuro da lavoura no Brasil levou o Ministério da Agricultura, no ano de 1878, a organizar um congresso agrícola na cidade do Rio de Janeiro a fim de discutir soluções para a crise vivenciada pela lavoura brasileira naquele momento. Foram propostas sete questões para discussão, e uma delas debatia a formação dos ingênuos como trabalhadores para a agricultura ${ }^{14}$. Tratava-se da quarta questão, que interrogava sobre os efeitos da lei de 1871 - mais precisamente, sobre a expectativa quanto às crianças livres, filhas de mães escravas, em relação ao mercado de trabalho e sua permanência nas plantações.

Os fazendeiros participantes do congresso agrícola que se mostravam favoráveis ao aproveitamento dos libertos sempre apontavam para a necessidade de imbuir nos ingênuos a ética do trabalho através de treinamento agrícola. Através dos discursos dos participantes do congresso de 1878, Fonseca observa que a reivindicação em torno do ensino agrícola pode ser considerada não somente no sentido de disciplinar os trabalhadores para que eles fossem retidos na agricultura, mas também como meio de impedir que o processo de libertação, sobretudo dos ingênuos, culminasse com uma debandada geral desses indivíduos para os centros urbanos.

Isto acarretaria não só um problema para a falta de estrutura das cidades, como também representaria uma perda da mão de obra considerada indispensável ao bom andamento dos trabalhos na lavoura (FONSECA, 2002, p. 90).

\footnotetext{
14 Tratou-se nesse congresso das seguintes questões: 1) Quais as necessidades mais urgentes e imediatas da grande lavoura?; 2) É muito sensível a falta de braços para manter, melhorar ou desenvolver os atuais estabelecimentos da grande lavoura?; 3) Qual o modo mais eficaz e conveniente de suprir essa falta?; 4) Poder-se-á esperar que os ingênuos, filhos de escravas, constituam um elemento de trabalho livre e permanente na grande propriedade? No caso contrário, quais os meios para reorganizar o trabalho agrícola?; 5) A grande lavoura sente carência de capitais? No caso afirmativo, é devido este fato à falta absoluta deles no país ou à depressão do crédito agrícola?; 6) Qual o meio de levantar o crédito agrícola? Convém criar estabelecimentos especiais? Como fundá-los?; 7) Na lavoura, têm-se introduzido melhoramentos? Quais? Há urgência de outros? Como realizá-los? (CONGRESSO AGRÍCOLA, 1878, p. 31).
} 
Entretanto, nem todos os congressistas concordavam com o aproveitamento dos ingênuos para o trabalho agrícola. Entre as razões para o pessimismo, estava a insubordinação dos ingênuos resultante do status de livres que carregavam. Segundo um congressista da cidade fluminense de Resende, "desde que eles obtenham a emancipação, a primeira coisa que devem querer é alcançar a liberdade" (CONGRESSO AGRÍCOLA, 1878 apud EISENBERG, 1980, p. 185). Dessa forma, não permaneceriam como lavradores, sendo "quase certo que fossem destinados a outras indústrias de maior vantagem no salário, ou ao exército, ou constituíssem uma população desocupada e indolente" (Ibidem). Outros, porém, que não viam com otimismo a possibilidade de os ingênuos servirem de mão de obra para as fazendas, insinuavam sua vocação para a posse de pequenas lavouras:

antes é de presumir, pela natural tendência do homem de procurar a sua independência, que os ingênuos morigerados e trabalhadores se esforcem por ser proprietários, e por conseguinte, se dediquem à pequena lavoura que demanda poucos capitais (Ibidem).

Entre os que viam os ingênuos como possíveis trabalhadores rurais destacavam a necessidade de fornecer-lhes educação agrícola. Pensando nisso, os agricultores reivindicavam com veemência a criação do ensino agrícola no país.

Do ponto de vista dos agricultores, esse tipo de ensino era fundamental para a transformação dos ingênuos em seres úteis, e também para apoiar o processo de modernização do trabalho nas fazendas (FONSECA, 2002, p. 83) ${ }^{15}$.

O discurso proferido pelo comendador Luiz Ribeiro de Souza, da cidade de Resende, durante o Congresso Agrícola de 1878, salienta a importância dos

15 Outra opção para a formação dos ingênuos em trabalhadores agrícolas seria a submissão dos mesmos, desde a infância, ao trabalho agrícola, tornando-os acostumados a ele ao completarem 21 anos (SIMÃO, 2004). 
estabelecimentos agrícolas e industriais, onde comece a tratar desses ingênuos, onde se lhes dê a verdadeira educação agrícola, onde possam aprender a ler, escrever e contar; onde, além desses princípios de educação, ainda tenham alguns estudos teóricos e práticos da agricultura do país (CONGRESSO AGRÍCOLA, 1878, p. 201 apud LANNA, 1989, p. 63).

Até o ano de 1879, há um esforço em construir uma estrutura que possibilitasse a educação das crianças nascidas livres de mãe escrava entregues ao Estado (FONSECA, 2002, p. 66). Esse ano constituiu-se em um marco para a ação do governo por ser aquele em que as primeiras crianças nascidas livres de mãe escrava completariam 8 anos, podendo, a partir dessa idade, ser entregues ao Estado, ou retidas nas mãos dos senhores. Embora evidenciasse certa confiança em relação ao fato de que os senhores das mães optariam pela manutenção das crianças nascidas livres de mulheres escravas como mão de obra, o ministro da agricultura, João Lins Vieira Cansanção Sinimbu, não deixou de demonstrar apreensão quanto à possibilidade de esses senhores acionarem o Estado para receber a indenização de Rs. $600 \$ 000$ e entregar as crianças para que completasse sua educação.

Segundo estimativa do Ministro da Agricultura tomando por base dados coletados no ano de 1877 em relação às crianças que foram matriculadas, em 1878 o país teria 192.000 crianças nascidas livres de mãe escrava. (...) Se todas elas fossem entregues ao Estado logo que a lei completasse oito anos, resultaria em um colapso na organização financeira e burocrática do governo, pois, não só acarretaria a mobilização de enormes recursos para a indenização dos senhores, como não haveria um número de associações que pudessem receber tal quantidade de crianças (FONSECA, 2002, p. 66).

Porém, contrariando a expectativa de que cerca de um sexto dos ingênuos seria entregue ao Estado, o que de fato ocorreu foi a opção generalizada dos senhores por utilizar os serviços dos menores até que completassem 21 anos. Segundo dados obtidos no Relatório do Ministro da Agricultura de 1885, do total de 403.827 crianças apenas 113 foram entregues ao Estado em troca da indenização de Rs. 600\$000, número 
que não correspondia a 1\% do número total de crianças nascidas livres de mãe escrava em todo o país (CONRAD, 1978, p. 144).

A preferência dos senhores em manter os ingênuos em suas propriedades levou a uma mudança de ação do governo em relação às associações criadas para assistir àquelas crianças. No período posterior a 1879, ainda são criadas algumas novas instituições dessa natureza, mas não foram apresentadas com a mesma preocupação que as anteriores e tampouco receberam os mesmos incentivos financeiros das surgidas antes de $1879^{16}$.

Portanto, as instituições que surgiram em clima de euforia e expectativa em relação à educação de crianças recém-saídas da escravidão, passaram a enfrentar problemas e a modificar suas formas de atuação durante os anos que compreendem a década de 1880. Esses problemas ligavam-se, em parte, à perda do auxílio financeiro do Ministério da Agricultura, para quem as associações passaram, após 1879 , a não ter função, pois as crianças que deveriam ser educadas nessas instituições foram retidas nas mãos dos senhores (FONSECA, 2002, p. 112).

A partir de então, tais associações focam o problema da infância desamparada - que passava pelos ingênuos, mas também pelas crianças órfãs, abandonadas, desvalidas, etc. Não apenas as descendentes de escravos, mas as crianças em geral, nacionais e estrangeiras, provenientes das camadas mais pobres passaram, então, a constituir objeto de atenção nas últimas décadas do século XIX. Para entendermos tal política faz-se necessário lembrar o contexto da crise da escravidão e as discussões em torno da necessidade de se formar trabalhadores livres e disciplinados. Neste contexto, a criança, principalmente aquela pertencente aos setores mais pobres da sociedade, era vista como responsável pelo devir, cidadã do futuro que, através do trabalho, elevaria a pátria ao "progresso" e à "civilização".

${ }^{16}$ Entre as instituições que surgiram nesse período, o autor cita: a Colônia Orfanológica Blasina, fundada em 1881, no município de Santa Luzia, província de Goiás; a Colônia Orfanológica Cristina, fundada em 1880, no Ceará; a Colônia Nossa Senhora do Carmo do Itabira, fundada em 1884, em Minas Gerais; e o Instituto Taubateano de Agricultura, Artes e Ofícios fundado em 1888, na cidade paulista de Taubaté (PAPALI, 2003, p.128). 


\section{Úteis a si e à nação: políticas para transformar crianças pobres em trabalhadores}

Os ingênuos e demais crianças livres pobres deveriam ser encaminhados para uma vida digna, por meio da educação para o trabalho. Resgatando o discurso político do final do século XIX relativo à província mineira, Ana Lúcia Lanna demonstrou que a educação agrícola era vista como a "necessidade mais urgente da lavoura", pois que "educados os lavradores, haverá de sobra terras e braços” (LANNA, 1989. p. 63).

O Relatório da Assembleia Legislativa da Província de Minas Gerais do ano de 1855 já trazia o desejo de criar uma escola de agricultura. Entre as razões para tal empreendimento, estava a falta de braços trabalhadores na província ${ }^{17}$. A primeira escola agrícola em Minas Gerais somente foi estabelecida no ano de 1869, com a inauguração da escola agrícola fundada em Juiz de Fora. O relatório da província do ano de 1871 revela que a escola de agricultura de Juiz de Fora abrigava e educava 40 alunos.

Na lei n. 1.741 foi-lhe concedida a subvenção de Rs 6:00o\$0oo com obrigação de receber e sustentar a sua custa pelo menos 12 órfãos pobres enviados pelas câmaras dos municípios, em que se cultiva café ${ }^{18}$.

Nesta mesma lei, autorizou-se despender desde então a quantia necessária para fundar três outras escolas práticas de agricultura nas imediações das cidades de Ouro Preto, São João del-Rei e Campanha. Em 1881, foi criada a Escola Agrícola do Vale do Piracicaba.

Além de outras é sua obrigação instruir em agronomia brasileira, teoria e prática, os alunos da escola e a quaisquer habitantes do campo que ali desejem receber o ensino profissional. Funciona na fazenda denominada Palestina no termo do Itabira ${ }^{19}$.

17 Relatório apresentado pela assembléia legislativa provincial de Minas Gerais na segunda sessão ordinária da décima legislatura de 1855, p.11.

18 Relatório apresentado pela Assembléia legislativa provincial de Minas Gerais na sessão extraordinária de 1871, p.43.

19 Relatório apresentado pela assembléia legislativa provincial de Minas Gerais em 7 de agosto de 1881, p. 66. 
No mesmo ano, foi inaugurado o Asilo Agrícola da capital mineira, naquele momento, Ouro Preto.

Já foram nele matriculados cinco menores, que recebem por enquanto somente ensino prático, alimentação, vestuário e mais cuidados. (...). Não se encontrando aqui facilmente pessoal assaz idôneo para o ensino de agricultura, preparo e amanho da terra, segundo os melhores métodos hoje conhecidos, solicitei do ministério da agricultura que se servisse de fazer com que se dirijam para esta capital três ou quatro famílias de imigrantes, aptas para aquele fim $^{20}$.

O diretor do Asilo Agrícola, senhor Domingos Martins Guerra, informa ao governo provincial, no ano de 1882, que a admissão de menores desvalidos

será mesmo necessário e útil, não só para amparar tantos órfãos e desvalidos, que criados nesta boa prática se tornarão depois melhores do que estes adultos já viciados e indolentes que mal se sujeitam ao trabalho ${ }^{21}$.

Luciana de Araújo Pinheiro, investigando os relatórios ministeriais e policiais da Corte, produzidos no período 1879-1889, também observou a preocupação da capital do Império com os problemas decorrentes da escassez da mão de obra escrava e da possibilidade de contorná-los através da formação da criança pobre.

Assim como os ministros, as autoridades policiais são unânimes em apontar a necessidade de dar à infância instrução primária atrelada ao ensino profissional. Mas se os primeiros não apontavam em que tipo de atividade inserir os menores, os chefes de polícia estavam certos de que o trabalho agrícola era a melhor forma de encaminhamento para a infância pobre da Corte. Esta seria, afinal, uma forma fácil de lidar com a escassez de mão-deobra nas lavouras, consequente da crise do escravismo, e de buscar resolver o problema causado pelo excesso de meninos e meninas pobres nas ruas do Rio de Janeiro (PINHEIRO, 2003, p. 70).

${ }^{20}$ Relatório do Presidente da Província de Minas Gerais, 1881, p. 13.

${ }^{21}$ Fala que o exmo. sr. dr. Theophilo Ottoni dirigiu à Assembléia Provincial de Minas Gerais em 1882, anexo, F, p. 3-4. 
Célia Maria Marinho de Azevedo resgatou as idéias do Visconde e Marechal-de-Campo Henrique Pedro Carlos de Beaurepaire-Rohan que, sobre o processo de transformação do trabalho, publicou, em 1878, $O$ futuro da grande lavoura e da grande propriedade no Brasil. Segundo Beaurepaire-Rohan, o essencial para a formação do homem livre como trabalhador era acostumá-lo desde a mais tenra idade ao trabalho voluntário, o que poderia ser obtido a partir da criação de escolas especializadas em educação industrial. Enquanto não fosse possível fundar essas escolas, ele recomendava, o ensino dos ingênuos pelos fazendeiros. "Somente assim, os descendentes dos escravos poderiam se tornar, no futuro, 'homens moralizados, dignos cidadãos de um país civilizado" (BEAUREPAIRE-ROHAN, 1878, p. 21-22 apud AZEVEDO, 2004, p. 43).

Além da educação agrícola, os meninos pobres poderiam ser "educados" através das Companhias de Aprendizes de Marinheiros e Artesãos Aprendizes - vinculadas ao Arsenal da Marinha - e dos Menores dos Arsenais de Guerra e Depósito de Aprendizes Artilheiros - vinculadas ao Arsenal de Guerra. Nessas instituições, os meninos eram qualificados para tornarem-se mão de obra desses arsenais. Além da solicitação do responsável pela criança, que deveria provar sua indigência, as exigências para a admissão eram o menino ter entre 10 e 17 anos para os aprendizes de marinheiros e entre 7 a 12 para as outras instituições, apresentar uma constituição robusta e ser brasileiro (BULCÃO, 1992, p. 44-45).

As Casas de Educandos Artífices representaram outro modelo de ensino de ofícios vigente no país durante a segunda metade do século $\mathrm{XIX}^{22}$.

${ }^{22}$ Irma Rizzini menciona as seguintes Casas dos Educandos Artífices fundadas na segunda metade do século XIX: Ceará (1856), Alagoas (1858), Amazonas (1858) e Rio grande do Norte (1859). Na província da Paraíba, fundou-se uma Casa dos Educandos Artífices em 1865. Em 1875, foi fundado no Rio de Janeiro o Instituto Profissional Masculino. A Colônia Orfanológica Isabel, localizada em Pernambuco, também foi criada no ano de 1875 (RIZZINI, 2004, capítulo 3). 
A província mineira, a exemplo de outras províncias, também intentava criar em sua capital um instituto de educandos artífices. Para tal fim, o governo provincial pensava em aproveitar o Jardim Botânico

no espaçoso edifício que lá existe, o que poderá conter muitos meninos, órfãos ou indigentes que aprendam primeiras letras, desenho linear, geometria e música, e habituem-se desde logo a trabalhar, aprendendo algum ofício mecânico nas oficinas que se estabelecem. Aos poderes gerais devemos solicitar todo o auxílio para a fundação de tal estabelecimento, e nos cofres provinciais uma subvenção ${ }^{23}$.

O relatório de 1873 afirma que todo o investimento aplicado na criação do instituto de educandos artífices será recompensado em quatro anos.

Basta refletir na despesa anual que a província faz com obreiros imperfeitos, e objetos indispensáveis para o regular andamento do serviço público, para se conhecer de quanta utilidade não será para a província um tal estabelecimento. Dentro de quatro anos pode o artífice prestar serviços; e obrigado a servir a província por igual tempo, e por uma módica gratificação diária, que pode ser a terça parte do líquido de seus salários, descontado o sustento e vestuário, seguramente o produto compensará a despesa com ele feita, deixando um remanescente avantajado em bem dos futuros artífices ${ }^{24}$.

O relatório do ano de 1876 lembra que a criação desse estabelecimento vincula-se ao

intuito humanitário de amparar tantos menores indigentes e desvalidos que a mingua de proteção, se pervertem, não é só uma obra de filantropia, é ainda mais um dos mais instantes reclamos da sociedade. Esses infelizes, não tendo quem lhes dirija os primeiros passos na vida, lhes cultive a inteligência, lhes refreie os maus instintos, são forçosamente arremessados ao crime pela corrupção e pela miséria. Os poderes constituídos têm o dever de sustentá-los na queda, de velar sobre eles e de, educando-os ao trabalho, torná-los cidadãos úteis a si e à sociedade. (...). Dai instrução moral e religiosa, proporcionai um ofício a esses desventurados, donde possam tirar sua futura subsistência e

23 Relatório que apresentou ao exmo. sr. vice-presidente da província de Minas Gerais, dr. Francisco Leite da Costa Belém por ocasião de lhe passar a administração em 20 de abril de 1872, 107-108.

24 Relatório de Presidente da Província de Minas Gerais, 15 de janeiro de 1873, p.12. 
tereis obreiros do progresso, assim cumprindo uma augusta missão ${ }^{25}$

O relatório de presidente da província de Minas Gerais do ano de 1880 mencionou que

pelas leis números 2.228 de 14 de julho de 1876, 2.543 de 6 de dezembro de 1879, 2.634 de 7 de janeiro do corrente ano foram criados diversos estabelecimentos tendentes a difundir na província o ensino profissional, tais como: instituto de menores artífices nesta capital e cidades de Pouso Alegre e Montes Claros; um liceu de artes e ofícios na cidade do Serro e uma escola de agricultura, em ponto não determinado, com o fim de formar engenheiros agrícolas e bacharéis em ciências físicas e naturais. Por enquanto só foi instalado o liceu de artes e ofícios; devendo também tê-lo sido o instituto de menores artífices de Montes Claros $^{26}$.

Os estabelecimentos de ensino de ofícios não eram instituições de caridade como os asilos que recolhiam expostos e abandonados, os quais não esperavam ter nenhum retorno financeiro de suas atividades. As casas, institutos e colônias de ensino profissional previam, em seus regulamentos, indenizações por parte dos educandos ou de suas famílias pelos gastos realizados com a educação, alimentação e vestuário. Além disso, as oficinas deveriam render lucro para cobrir as despesas dos estabelecimentos. As indenizações com a educação dos meninos deveriam ser pagas após o término da formação, permanecendo o educando por mais três anos na instituição, trabalhando na oficina. A única forma de não cumprir esta obrigação seria a família indenizar a instituição (RIZZINI, 2004, p. 177-178)27.

25 Relatório apresentado pela Assembléia Legislativa Provincial de Minas Gerais na sessão ordinária de 1876, p.16.

26 Fala que a Assembléia Legislativa Provincial de Minas Gerais dirigiu em 25 de setembro de 1880, ao exmo. sr. cônego Joaquim José de Santana, segundo vicepresidente da mesma província por ocasião da abertura da primeira sessão ordinária

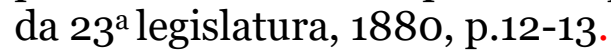

27 Das instituições estudadas por Rizzini, nenhuma atingiu semelhante meta. As despesas eram sempre maiores do que a renda das oficinas, fazendo com que as instituições dependessem de subvenções governamentais e outros recursos (RIZZINI, 2004, p.178). 
No Asilo de Meninos Desvalidos na Corte, criado em 1875, pelo Governo Imperial, a proposta educativa não se diferenciava substancialmente dos estabelecimentos de educandos artífices. A preocupação do asilo consistia em educar desvalidos, dando-lhes uma profissão considerada digna e adequada à classe social a qual pertenciam. O principal objetivo do asilo era incentivar o processo civilizatório brasileiro promovendo o cuidado, a formação para a cidadania e a educação das crianças desvalidas. Entretanto, as fichas com os dados dos alunos analisadas por Silvania Damacena Martins revelam a heterogeneidade da clientela atendida pelo asilo, que muitas vezes não se enquadrava em um padrão cuja marca fosse a carência. Percebe-se, então, que o asilo fugia assim de sua vocação inicial, cedendo a uma clientela nãodesvalida que conseguia sua inserção através de cartas de referência (MARTINS, 2004) ${ }^{28}$.

Tal instituição merece destaque por apresentar-se como modelo para o restante do país quanto ao atendimento de meninos desvalidos e por oferecer, além do ensino primário, oficinas profissionais em que os alunos adquiriam algum ofício ${ }^{29}$. Como forma de pagamento, ao completar a maioridade, o asilado cumpria três anos de trabalho obrigatório e era posteriormente encaminhado para oficinas públicas ou privadas.

O asilo era a expressão de um projeto que visava "moralizar" a sociedade transformando suas bases por meio da educação. Os meninos trabalhavam em oficinas e produziam bens que serviam para uso da própria instituição.

Muitos alunos eram incentivados a prosseguir nos estudos, e neste aspecto o Asilo em nada se assemelha a outras instituições. Mas a maioria, ao sair do estabelecimento, parece ter se dedicado

\footnotetext{
${ }^{28}$ Rizzini também constatou que, muitas vezes, o favorecimento político podia alterar os critérios regulamentares dos institutos. Sobre isso, Rizzini encontra explicação na política clientelista do Estado imperial, que tendia a favorecer seus dependentes mediante o esquema do favor (RIZZINI, 2004, p.184).

29 O quadro de funcionários do Asilo de Meninos Desvalidos traz, além dos administradores e prestadores de serviços, as funções de professor de primeiras letras, professor de álgebra e geometria, professor de desenho, professor de música, professor de ginástica, mestre alfaiate, mestre carpinteiro, mestre encadernador, mestre sapateiro (MARTINS, 2004, p. 32).
} 
aos trabalhos manuais - como, por exemplo alfaiates, operários em metais, em madeira, em tecidos, sapateiros, chapeleiros, pintores - aprendidos na instituição, como indicam as recomendações feitas pelo diretor (MARTINS, 2004, p. 68).

Boa parte da sociedade ligava crianças pobres e trabalho como forma de evitar a marginalidade. Crianças na rua, portanto, precisariam ser encaminhadas aos juízes para lhes "arranjarem arrumação". Em contraposição à rua, local perigoso e próprio à vagabundagem, configurava-se a possibilidade de regenerar moralmente a infância desvalida através da educação pelo trabalho. A ideologia do trabalho, como destaca Bulcão, servia como estratégia de regeneração, controle social e ordenação urbana. O disciplinamento das classes populares, a partir da educação de suas crianças também foi um objetivo importante e que não pode ser ignorado. A “inoculação íntima do amor ao trabalho" é um mote que aparece insistentemente nos regulamentos dos asilos e nos escritos de seus defensores. A obediência, o respeito à hierarquia e a promoção da civilidade dos costumes constituem objetivos importantes dos internatos para desvalidos (BULCÃO, 1992, p. 38).

Para os casos mais complicados, como crianças e jovens que já estivessem há algum tempo nas ruas (e, por isso, segundo as autoridades, já haviam adquirido alguns vícios transformando-se em "pequenos vadios ou corrompidos"), foram criadas instituições assistenciais com o objetivo de retirá-los de circulação e reeducá-los através do trabalho, coibindo, assim, a existência de futuros ociosos e criminosos ${ }^{30}$. Tais menores

3o Para Fortaleza nas últimas décadas do século XIX, Sousa constatou que os órfãos da seca, que sobreviveram à varíola e não migraram para o Norte e o Sul, formaram bandos a perambular pelas ruas em grupos cometendo assaltos, furtos, arrombando lojas e quintais. No ano de 1880 , foi fundada a Colônia Cristina, que tinha como finalidade recolher, conter, corrigir e educar, através do trabalho e da disciplina, as crianças que circulavam pelas ruas de Fortaleza. "A Colônia Cristina funcionou de 1880 a 1915 em torno de três concepções fundamentais: asilo para órfãos desvalidos, escola agrícola e colônia correcional. Esses modos de organização da Colônia foram empregados de modo sucessivo, pois esta fora criada para ser abrigo de órfãos, depois transformou-se em escola agrícola para desenvolver a agricultura na província e, por último, acentuou-se o seu caráter de correção da infância denominada de vadia" (SOUSA, 2004, p. 67-68). No caso da Bahia, a análise de Walter Fraga Filho revelou que para conter a "infância perigosa" começaram a ser criadas, naquela província, ao 
deveriam receber, nessas instituições, uma formação voltada para o trabalho, principalmente o agrícola, que os capacitaria para o futuro. As instituições, ao segregar o menor carente, tirá-lo-iam das ruas, da vadiagem e do contato perigoso com familiares incapacitados. Salvar a infância carente para os dirigentes não significava garantir melhores condições de vida, mas modificar seu comportamento, que quase sempre destoava do desejado.

\section{Considerações finais}

Nos debates acerca da transformação do trabalho no Brasil, a preocupação em tornar o homem nacional um trabalhador adaptado à nova realidade - resultante do processo de abolição da escravidão - gerou uma grande discussão. Para aqueles que acreditassem no homem nacional (livre pobre, liberto e ingênuo) como mão de obra capaz de substituir o escravo, seria importante a efetivação de medidas para ótimo aproveitamento desses trabalhadores. Numa situação emergencial, a coação ao trabalho e a condenação à ociosidade parecia ser o principal mecanismo de adesão desses trabalhadores. Entretanto, uma outra proposta visava, em longo prazo, adequar a mão de obra nacional à nova conjuntura através da educação. Nesse processo de formação de trabalhadores via educação, as crianças desvalidas, muitas vezes, descendentes de ex-escravos, eram o alvo principal, pois poderiam ser educadas desde cedo para atender às novas expectativas de trabalho.

Além de garantir mão de obra, a educação profissional de crianças pobres era vista como uma das soluções para o problema da infância abandonada, desvalida ou viciosa. Buscava-se disciplinar essas crianças para o trabalho e afastá-las da ociosidade, recuperando socialmente aquelas que perambulavam pelas ruas, evitando que se inserissem ou permanecessem na marginalidade. Assim, além da preparação de

final do século XIX e primeiras décadas do XX, instituições especializadas, como as colônias correcionais e agrícolas, que os recebiam visando a educá-los pelo e para o trabalho (FRAGA FILHO, 1996, p. 120-130). 
trabalhadores, a educação de crianças pobres funcionava, também, para a manutenção da ordem.

A fim de atender à demanda, várias instituições foram criadas para receber meninos e meninas pobres: Colônias Orfanológicas, Asilos, Companhias de Aprendizes Artífices, Companhias de Aprendizes Marinheiros, Casa dos Educandos Artífices, etc. Instituições que tinham como propósito cuidar da educação de crianças ingênuas, órfãs, abandonadas, desvalidas. Normalmente, ocupavam-se da instrução elementar, da formação cívica e da capacitação profissional das crianças que recebiam. Quanto à formação profissional, predominavam os elementos da educação agrícola, mas as crianças também poderiam ser educadas para os ofícios.

Ao final do processo de formação da criança, esperava-se encontrar um trabalhador adequado ao sistema de trabalho que substituiria o trabalho escravo. Nesse sentido, as crianças passam a ser vistas como verdadeiras responsáveis pelo devir; futuros cidadãos sobre os quais recairiam as tarefas de elevação da pátria ao progresso e à modernização.

\section{Referências}

ABREU, M.; MARTINEZ, A. Olhares sobre a criança no Brasil perspectivas históricas. In: RIZZINI, I. (org.). Olhares sobre a criança no Brasil. Rio de Janeiro: Editora Universidade Santa Úrsula, 1997, p. 19-37. AZEVEDO, C. M. M. Onda negra, medo Branco: o imaginário das elites (século XIX). São Paulo: Annablume, 2004.

BULCÃO, A. L. Meninos maiores: o conflito da menoridade e maioridade no Rio de Janeiro entre 1890 e 1927. Dissertação (Mestrado) Universidade Federal do Rio de Janeiro, Rio de Janeiro. 1992.

CONRAD. R. Os últimos anos de escravatura no Brasil. Rio de Janeiro: Civilização Brasileira, 1978.

COSTA, E. V. Da senzala à colônia. São Paulo: Unesp, 1998. 
Unesp, 1999.

. Da monarquia à República: momentos decisivos. São Paulo:

EISENBERG, P. L. A mentalidade dos fazendeiros no congresso agrícola de 1878. In: LAPA, J. R. A. (org.). Modos de produção e realidade brasileira. Petrópolis: Vozes, 1980, p. 167-194.

FONSECA, M. V. A educação dos negros: uma nova face do processo de abolição da escravidão no Brasil. Bragança Paulista: Edusf, 2002.

FRAGA FILHO, W. Meninos vadios, moleques e peraltas. In: Mendigos, moleques e vadios na Bahia do século XIX. São Paulo: Hucitec, 1996.

GEBARA, A. O mercado de trabalho livre no Brasil (1871-1888). São Paulo: Brasliense, 1986.

KOWARICK, L. Trabalho e vadiagem: a origem do trabalho livre no Brasil. São Paulo: Brasiliense, 1987.

LAMOUNIER, M. L. Da escravidão ao trabalho livre (a lei de locação de serviços de 1879). Campinas: Papirus, 1988.

- Agricultura e mercado de trabalho: trabalhadores brasileiros

livres nas fazendas de café e na construção de ferrovias em São Paulo, 1850-1890. Estudos Econômicos. São Paulo, 37(2): 353-372, 2007.

LANNA, A. L. A transformação do trabalho. Campinas: Unicamp, 1989.

MARCÍlLIO, M. L. História social da criança abandonada. São Paulo: Hucitec, 1998.

MARTINEZ, A. F. Educar e Instruir: olhares pedagógicos sobre a criança pobre no século XIX. In: RIZZINI, I. (org.) Olhares sobre a criança no Brasil - séculos XIX e XX. Rio de Janeiro: Editora Universitária Santa Ursula/Amais, 1997, p. 155-184.

MARTINS, S. D. Reformando a Casa Imperial: assistência pública e a experiência do asilo de meninos desvalidos na Corte (1870-1888). Dissertação (Mestrado) - Universidade Federal do Rio de Janeiro, Rio de Janeiro, 2004.

PAPALI, M. A. Escravos, libertos e órfãos: a construção da liberdade em Taubaté (1871-1895). São Paulo: Annablume: FAPESP, 2003.

PINHEIRO, L. A. A civilização do Brasil através da infância: propostas e ações voltadas à criança pobre nos finais do Império (1879-1889). Dissertação (Mestrado) - Universidade Federal Fluminense, Niterói, 2003.

RIZZINI, I. O cidadão polido e o selvagem bruto: a educação dos meninos desvalidos na Amazônia Imperial. Tese (Doutorado) - Universidade Federal do Rio de Janeiro, Rio de Janeiro, 2004. 
SOUSA, J. P. A mão-de-obra de menores escravos, libertos e livres nas instituições do Império. In: Escravidão: ofícios e liberdade. Rio de Janeiro: APERJ, 1998, p. 33-63.

SOUSA, J. W. F. Artífices, criadas e chicos: as experiências urbanas das crianças órfãs e pobres em Fortaleza de 1875-1915. Dissertação (Mestrado) - Pontifícia Universidade Católica de São Paulo, São Paulo, 2004. VENÂNCIO, R. P. Os aprendizes da guerra. In: PRIORE, M. (org.). História das crianças no Brasil. São Paulo: Contexto, 2002, p. 193-209.

\section{Fontes}

BEAUREPAIRE-ROHAN. H. P. C. O futuro da grande lavoura e da grande propriedade no Brasil. Rio de Janeiro: Nacional, 1878

BRASIL, RIO DE JANEIRO. Lei $\mathrm{n}^{\mathrm{O}}$. 2.040, 28 set.1871. Declara de condição livre os filhos de mulher escrava que nasceram desde a data desta Lei, libertos os escravos da Nação e outros, e sobre a libertação anual de escravos. Collecção das Leis do Império do Brasil de 1871. Tomo XXXI. Parte 1. Rio de janeiro, Typographia Nacional, 1871. Actos do Poder Legislativo de 1871. Parte 1, p.147-152.

CONGRESSO AGRÍCOLA DO RIO DE JANEIRO. Edição fac-similar dos anais do Congresso Agrícola, realizado no Rio de Janeiro em 1878. Introdução de José Murilo de Carvalho Disponível em: <https://archive. org/stream/congragri1878josemur\#page/n11/mode/2up $>$.

MALHEIRO, Agostinho Marques Perdigão. A escravidão no Brasil ensaio histórico-jurídico-social. Rio de Janeiro: Typ. Nacional, 1867. Em nosso texto, trabalhamos com uma reedição produzida pela editora Vozes no ano de 1976.

MINAS GERAIS. Relatórios dos Presidentes de Província e demais autoridades do Governo Mineiro. 1833-1889. Disponível em <http://wwwapps.crl.edu/brazil/provincial/minas_gerais $>$.

MINAS GERAIS. Leis Mineiras. 1850-1889. Disponível em <http:// www.nphed.cedeplar.ufmg.br/livro-da-lei-mineira>. 